Journal of Social Sciences 6 (1): 119-122, 2010

ISSN 1549-3652

(C) 2010 Science Publications

\title{
Ten Theses in Search of a Thesis for Late Modern Organizations
}

\author{
Hooman Attar \\ Macquarie Graduate School of Management, \\ 99 Talavera Road, Macquarie Park, Sydney, 2113, NSW, Australia
}

\begin{abstract}
Problem statement: Organizational studies frequently fail to integrate major sociological treatments of the problematic nature of contemporary society into their routine investigations. Approach: This study used the idea of risk management as a lever for integrating sociological explorations of the risk society and reflexive modernization into organizational studies, opening up the question of the restricted nature of organizational considerations of risk, the reasons for the degree of 'unreflexivity' that exists and how this might be investigated and addressed. The following ten 'theses' state some of the key assumptions that one 'thesis' is making in seeking to open up this debate. Conclusion/Recommendations: My proposal is to adopt a Latourian style that follows the actors involved in weaving together the micro and macro, discursive and non-discursive, elements of risk and its management.
\end{abstract}

Key words: Modernization, reflexive modernity, risk, risk society, uncertainty

\section{INTRODUCTION}

Despite its sometime critical edge, organizational studies frequently fail to integrate major sociological treatments of the problematic nature of contemporary society into their routine investigations (Clegg et al., 2006). This 'paper' outlines how one doctoral thesis is attempting to use the idea of risk management as a lever for integrating sociological explorations of the risk society and reflexive modernization into organizational studies. Its concern is to open up the question of the restricted nature of organizational considerations of risk, the reasons for the degree of 'unreflexivity' that exists and how this might be investigated and addressed. The following 'theses' state some of the key assumptions that the 'thesis' is making in seeking to open up this debate. The study is designed to foster discussion on the degree to which such an approach is distinctive and useful in prying open this area of organizational life and the kind of investigations that it should engender. Its focus and brevity is intended to support such a discussion.

Thesis 1 the quest for order: At the heart of modernity is a quest for order, unity and control. This quest seeks to eliminate ambiguity, chaos and disorder through systematic regulation of the individual, society and nature. Yet in so doing, modernity creates new forms of disorder and disunity. The attempts to regulate nature create systems of control that are not themselves subject to control (Beck, 1992). The spread of knowledge, rather than realizing the promised unity and authority, generates diverse knowledge claims and uncertainty about their foundations. The systematic specialization and integration of social institutions in an attempt to create more purposive and orderly administration generates a plurality of competing functions, levels, interests and life-worlds. As a result, in late modernity the idea of control as a 'plausible' future is becoming increasingly 'implausible' (Beck, 1992). Rather than one producing one agreed, authoritative and progressive path of development, it creates knowledge of and commitment to multiple alternative 'scenarios' (Giddens, 1999).

Thesis 2 from uncertainty to risk: Where modernity recognizes uncertainty it attempts to manage it as 'risk'. The attempted 'mastery of risk' (Bernstein, 1998) seeks to transform the recognition and acceptance of fundamental uncertainty into the calculated management of risk. The 'language of invention' is replaced by the 'language of investment' (Schon, 1967). The acknowledgement of uncertainty is transformed into calculations of risk that presume a clear and certain knowledge upon which the assessments of probability are made (Knight, 2006), (Schon, 1967). While marginalized critics offer advice on how best to confront irreducible uncertainties, there is a dominant 'cultural reification of risk' (Wynne, 2002). From its origins in shipping and insurance to contemporary icons of national prestige and corporate enterprise (rockets, spaceships and satellites, nuclear 
power and genetic engineering, an informated electronic network age and so on), the treatment of risk is subjected to 'hermeneutic sanitization' (Wynne, 2002), reducing risks to what can be addressed within official discourse. The existence of 'unintended consequences' (Beck, 1992) and 'unknown unknowns' (Beck, 2006) and (Wynne, 2002) are ignored or treated with shame and embarrassment.

Thesis 3 the great divide: The growth and dynamism of modernity had its origins in the splitting off of the 'technical' from the 'social', 'nature' from 'society', such that new technologies and interventions in nature were released from established social traditions. Yet this 'ability for their right hand to ignore what their left hand was doing' (Latour, 1993) was always a mythical divide, never real. What emerged were increasingly complex and more entangled 'socio-technical imbroglios', ever-spreading in their scope and becoming more diverse, more complex and more far reaching in their consequences. The 'modern constitution', established on the basis of the great divide is now being threatened as what modern are now 'explicitly saying' is what they had always been 'doing without saying' (Latour, 1993). With greater awareness of these 'leaky' imbroglios (Latour, 2003) and their 'intractable problems' (Latour, 2003), we are becoming 'conscious that consciousness does not mean full control" (Latour, 2003).

Thesis 4 manufactured uncertainty and organized irresponsibility: We live in a late modern social system that is suffering the unintended consequences of its own creations. It is dominated less by natural uncertainties, the dangers of pestilence and famine, scarcity and underproduction, than it is by 'manufactured uncertainties', (Beck, 1992; Giddens, 1999), a critical and growing mass of unintended side effects. 'I am hungry' (i.e., need) is replaced by 'I am afraid' (i.e., anxiety) (Beck, 1992). The initiators of new technologies, systems and controls are subject to the 'boomerang effect' (Beck, 1992) that come back to haunt the instigators and their victims. What appear as autonomous processes are governed by an 'organized irresponsibility' (Beck, 1992; Beck et al., 1994; Giddens, 1999) in which the authors of 'latent side effects' (Beck, 1992) are not liable, culpable or held responsible.

Thesis 5 overabundance of knowledge: The knowledge that we have developed, applied in our technologies and embedded in our systems of administration creates more rather than less unpredictability. The inherent skepticism of scientific knowledge, the existence of multiple competing knowledges and discourses and an increasing absorption in 'colonizing the future' all create uncertainty and dissatisfaction (Giddens, 1999). In the face of ongoing scientific development and the rapid changes wrought by the technologies and systems based on that development, we are witnessing the 'end of nature' and 'detraditionalization'. Our lives shift more frequently, they are no longer lived as fate or subordinate to the discipline of established tradition and we are continually disrupted by the consequences of the initiatives we have instigated to explore, harness and control nature. Technology is less of a savior than a problem and knowledge drawn into increasingly obsessive and inevitably unending and ultimately selfdefeating set of attempts to control the future.

Thesis 6 a reflex not reflexive society: In the face of a critical and growing mass of unintended consequences and side effects, individuals and institutions only have the time and space available to respond in a short term, reactive, 'reflex' like nature to the problems that are created (Beck, 1992; Beck et al., 2003). They and we, treat manufactured uncertainties as risks to be addressed within the narrow discursive frame of our immediate institutional sphere of 'control'. Broader reflection on the uncertain context within which we seek to 'manage' such risks appears 'unrealistic' and 'utopian'.

Thesis 7 selective inattention: Individuals, the public and institutions bracket out the phenomenon of systemic manufactured uncertainty. They are 'selectively inattentive' (Sullivan, 1953) to such problems by controlling their awareness of them. This represents an 'unwillingness to know' (Beck, 1999) or 'selective reception' (Beck, 1999) towards the source and effect of hazardous uncertainties. Our 'ignorance' or 'unawareness' (Beck, 1999) is denied, a myth of rationality (Schon, 1967) legitimates actions, represses anxieties and avoids the shame and embarrassment of acknowledging a lack of control. The messy, uncertain and unruly character of innovation is 'white boxed' (Wynne, 1988). Institutions with vested interests in particular trajectories or discursive agents committed to particular forms of knowledge create mythological justifications of their ability to manage the risks that they identify or create (Wynne, 1988). Taboos are created against any broader recognition of uncertainty and there is systematic 'forgetfulness' or deliberate 'ignorance of the past' (Beck, 1992; Schon, 1967). A cathartic brotherhood or community of 'reflex' 
responses is preferred to the fearfulness (Fromm, 1994) and anxiety (Sullivan, 1953) of admitting a lack of certainty and control and challenging institutionalized myths of how they are managing risk. In the face of uncertainty, this all encourages attention to shift rapidly 'from hysteria to indifference' (Beck, 1999)

Thesis 8 natural and manufactured ignorance: The failure to address fundamental uncertainties is also due to an 'inability to know' (Beck, 1999; Giddens, 1999), a condition deriving from either too little awareness or too much knowledge (Knight, 2006). On the one hand, within their frame, individuals and institutions simply 'do not know what they can not know' (Beck, 1999). On the other hand, the proliferation of knowledge claims means that no authoritative statements can be made about the cause and resolution of any problem (Giddens, 1999).

Thesis 9 public scepticism? The public within late modern societies appear at times to be uncertain and skeptical about the ability of such societies to control their destiny. This skepticism is the result of individuals being confronted by a disruptive process of 'detraditionalization' (such that life is no longer lived as ' fate', or according to pre-modern traditions) (Beck et al., 1994) and by increasing public distrust of the self-interested motives and claims to certainty made by large institutions (Hoffmann and Wynne, 2002; Wynne, 1988). The degree to which such skepticism exists is, however, uncertain and people are frequently distracted from, prevented from paying attention to, or silenced from voicing any such skepticism (Wynne, 1988; Lash et al., 1996).

Thesis 10 towards a solution: The solutions to such problems involve creating new discourses that recognize uncertainty and admit plurality and new institutional structures that are capable of and trusted to address such matters. Particular recommendations include:

- Moving from reactive 'back end' to proactive purposive 'front end' considerations of risk and establishing more effective rituals for democratic public decision making, rituals that acknowledge uncertainties and build trust (Wynne, 2002)

- Creating forms and forums of debate inside and outside organizations with a discourse that recognizes contradicting rationality claims and a set of consensual procedures to address these issues (Wynne, 2002)
- Slowing down modernization, overcome the 'great divide' in our thinking about nature/the technical and culture/society and establishing a 'parliament of things' capable of addressing the intertwined nature of our 'leaky' 'sociotechnical imbroglios' (Latour, 1993; 2003; 2005)

- establishing a more 'responsible reflexivity' in broader public decision-making arenas (Beck et al., 2003; Giddens, 1999)

\section{CONCLUSION}

Our current understanding of risk and its treatment appears somewhat limited. This applies to our understanding of the nature and dynamics of more restricted risk management discourses and agents as well as the discursive and institutional requirements for broadening our understanding of risk and its management. What kind of investigations are required to open up the black box of 'unreflexive' modernization in late modern organizations? Our proposal is to adopt a Latour (2005) style that follows the actors involved in weaving together the micro and macro, discursive and non-discursive, elements of risk and its management. Such an investigation could include (1) how such actors understand and deploy narrow views of risk and (2) whether and how they confront, repress or accept and deal with the broader issues of uncertainty as identified by authors of 'risk society'.

\section{REFERENCES}

Beck, U., 1992. Risk Society: Toward a New Modernity. 1st Edn., Sage, London, ISBN: 0803983468, pp: 272.

Beck, U., 1999. World Risk Society. 1st Edn., Polity Press, Cambridge, UK., ISBN: 0745622216, pp: 184.

Beck, U., 2006. living in the world risk society. Econ. and Soc., 35: 329-345. DOI: 10.1080/03085140600844902

Beck, U., A. Giddens and S. Lash, 1994. Reflexive Modernization: Politics, Tradition and Aesthetics in Modern Social Order. 1st Edn., Polity Press, Cambridge, UK., ISBN: 0804724725, pp: 225.

Beck, U., W. Bonss and Ch. Lau, 2003. The theory of reflexive modernization problematic. Hypotheses Res. Programme Theory Cult. Soc., 20: 1-33. DOI: 10.1177/0263276403020002001

Bernstein, P.L., 1998. Against the Gods: The Remarkable Story of Risk. 1st Edn., John Wiley and Sons, New York, ISBN: 0471295639, pp: 400.

Clegg, S., D. Courpasson and N. Phillips, 2006. Power and Organizations. 1st Edn., Sage, London, ISBN: 0761943927, pp: 457. 
Fromm, E., 1994. Escape from Freedom. 1st Edn., Owl Books, New York, ISBN: 0805031499, pp: 320.

Giddens, A., 1999. Risk and responsibility. J. Modern Law Rev., 62: 1-10. DOI: 10.1111/14682230.00188

Hoffmann, H. and B. Wynne, 2002. In risk assessment, one has to admit ignorance. Nature, 416: 14. DOI: $10.1038 / 416123 a$

Knight, F., 2006. Risk, Uncertainty and Profit. 1st Edn., Dover Publications, New York, USA., ISBN: 0486447758, pp: 448.

Latour, B., 1993. We Have Never Been Modern. 1st Edn., Harvester Wheatsheaf, Brighton, ISBN: 0674948394, pp:157.

Latour, B., 2003. Is re-modernization occurring-and if so, how to prove it? A commentary on ulrich beck. J. Theory Cult. Soc., 20: 35-48. DOI: 10.1177/0263276403020002002

Latour, B., 2005. Reassembling the Social: An Introduction to Actor-Network Theory. 1st Edn., Oxford University Press, Oxford, ISBN: 0199256047, pp: 301.

Lash, S., B. Szerszynski and B. Wynne, 1996. Risk Environment and Modernity: Towards a New Ecology. Sage, London, ISBN: 080397938X, pp: 294.
Schon, D.A., 1967. Technology and Change: The New Heraclitus. 1st Edn., Dell Publishing, New York, ISBN: 0080124925, pp: 270.

Sullivan, H.S., 1953. The Collected works of Harry Stack Sullivan. 1st Edn., The Norton Library, New York, pp: 38-77.

Wynne, B., 1988. Unruly technology: Practical rules, impractical discourses and public understanding. J. Soc. Stud. Sci., 18: 147-167. http://www.jstor.org/stable/285380

Wynne, B., 2002, Risk and environment as Legitimatory discourses of technology: Reflexivity inside out? J. Curr. Soc., 50: 459-477. DOI: $10.1177 / 0011392102050003010$. 